\title{
IMPROVING RELATIONSHIP QUALITY DURING THE CRISIS
}

\author{
Marta Estrada Guillén \\ Diego Monferrer Tirado \\ Miguel Ángel Moliner Tena \\ Universitat Jaume I, Castellón (Spain)
}

\begin{abstract}
The severe economic crisis in Spain has had a considerable impact on the financial sector and has led to deep and widespread restructuring in the industry. The combination of a vigorous expansion policy and the burst of the housing bubble brought about an economic depression with serious emotional consequences. As a result, customers have had to use their emotional intelligence to manage a range of emotions, many of them negative, and this management has affected their perceived quality of their relationship with their bank. Sobre esta base, in this article desarrollamos un planteamiento teórico inicial en el que se plantea como hipótesis de partida la influencia de customers' emotional intelligence sobre relationship quality. Adicionalmente, se plantea el estudio de las posibles interrelaciones existentes entre las tres variables que conforman the macro-construct of relationship quality, made up of satisfaction, trust and loyalty. Results from a sample of 1125 customers in a study using structural equations models nos permiten confirm all these relationships in a reflection on the need to generate marketing strategies that can maximise customers' positive emotional performance. Banks'more traditional strategies must therefore be reviewed, with efforts particularly focusing on the most tangible aspects of the service, creating emotionally attractive banking environments.
\end{abstract}

KEYWORDS. Emotional intelligence, relationship quality, Spanish banking sector, crisis

JEL: M3

\section{Introduction}


The deep economic crisis that began in 2008 has had a particularly severe impact in the Spanish financial sector. A clear illustration of this is the practical disappearance of savings banks, which before the crisis held some $50 \%$ of all deposits. The combination of an aggressively expansive banking policy and the bursting of the housing bubble precipitated a serious economic depression in the country. Although the effects of the crisis at a macroeconomic level have reached the front pages of the main international newspapers less academic attention has been paid to its impact at the microeconomic level (Monferrer et al., 2016). The dramatic reduction in credit for households and small businesses, the payment of exhorbitant commissions, the preferred shares scandal and the harsh bank restructuring policy are just some of the factors at the heart of a fierce social and political debate that has brought into question the solidity, honesty and credibility of the banking sector (Bennet \& Kottasz, 2012; Bekaert et al., 2014; Hansen, 2014; Gijsenberg et al., 2015; Monferrer et al., 2016).

This situation has given rise to an emotional environment that more than ever before has conditioned customers' relationship with their banks. Hence, while the recession is still fresh in people's minds, it is pertinent to study how this serious situation has affected customers' behaviour and their day-to-day relationships with the banks (Rollins et al., 2014). In this context, we believe variables traditionally studied in the literature such as trust, satisfaction and loyalty (relationship quality) should be reviewed in order to uncover any possible deviations from what is usually reported in the literature. This study therefore falls within the main present and future research lines proposed by institutions such as the European Union and the Marketing Science Institute (MSI), which in an attempt to provide solutions to the numerous challenges left in the wake of the economic and financial crisis, calls for priority research on the crisis of trust in the banking sector (MINECO, 2017; MSI, 2014, 2016). In this vein, the main innovation of the present study lies in the model it proposes that in addition to studying the relationship quality construct in the context of the banking crisis, also relates it with the more emotional and affective aspect of the crisis, examining how the way customers manage their emotions through their emotional intelligence (henceforth EI) has affected the perceived quality of the relationship with their bank. Thus, although in recent years there has indeed been some research interest in the affective nature of satisfaction and its consequences for trust in, and loyalty to, financial institutions (Amin, 2016; Bapat, 2017; Kaura et al., 2015; Monferrer et al., 2016; Sayani, 2015), few studies have 
analysed the affective antecedent of satisfaction in situations as adverse as those we deal with in this paper (Chebat \& Slusarczyk, 2005; Schoefer \& Ennew, 2005). In general, the study of emotions and EI is notably still in its infancy in the field of marketing (Deeter \& Sojka, 2003; Heffernan et al., 2008; Kidwell et al., 2008; Maguire \& Geiger, 2015; Rozell et al., 2004), and focuses almost exclusively on training the socioemotional skills that enhance the efficiency of sales staff and service providers, or as a formula to increase purchase intention (Deeter \& Sojka, 2003; Higgs, 2004). The reason for this may lie in the long-established interest in the field of organisational psychology in studying the relationship between employees' EI, performance at work, job satisfaction and organisational commitment, among others (Abraham, 2000; Cherniss, 2001; Zeidner et al., 2004). This gap in the research prompted the MSI (2016) to identify the study of emotions in consumer behaviour as a priority research area. Other authors had previously highlighted the need to determine the effects of emotions in the banking context, and to delve into the question of creating solid relationships that help prevent disloyalty and customer churn (Maguire \& Gieger, 2015; Marinkovic \& Obradovic, 2015).

Bearing in mind the research recommendations from the Marketing Science Institute and other authors, we propose analysing the impact that customers' management of emotions through their EI has had on the perception of relationship quality offered by the Spanish banking sector in the context of the banking crisis. Thus, from the academic point of view, the originality of this project lies in creating a theoretical model that integrates psychological variables such as customers' EI with more traditional marketing research variables (satisfaction, trust and loyalty) that have been severely challenged in the context of the banking crisis.

In this paper we first discuss the theory of the EI concept and relationship quality; we then describe the methodology used and analyse the results; finally, we draw conclusions that will enhance our understanding of bank customers during the previous crisis, with the aim of providing effective contributions to future proposals for relational strategies in the Spanish financial sector.

\section{Literature review}

\subsection{Emotional intelligence}


The concept of emotion comes from the French emouvoir, meaning to stir up or move, and is understood to be the driving force behind certain actions. Emotions are, in sum, the organism's response to certain environmental stimuli (Chiva \& Habbib, 2015). The literature provides numerous definitions for emotions, but today the consensus is adeptly summarised by Mayer et al. (2008), who consider them to be "coordinated responses to changes in the environment that involve invoking specific subjective experiences, activating relevant cognitions, $[\ldots]$, coordinating bodily states so as to prepare for certain reactions, [...] and appraising the ongoing situation for changes" (Vigoda \& Meisler, 2010; Zárate \& Matviuk, 2010). Both positive and negative emotions are perceived, understood, facilitated and managed through the competency known as EI (Mayer \& Salovey, 1997). Aristotle defined EI as "the ability to be angry with the right person, to the right degree, at the right time, for the right purpose and in the right way" (Zárate \& Matviuk, 2010). In turn, Salovey and Mayer (1990) define it as “the ability to monitor one's own and others' feelings, to discriminate among them, and to use this information to guide one's thinking and action".

Two of the main approaches used in the study of EI are the theoretical ability models, based on the mental abilities that allow information from emotions to be used to improve cognitive processing; and mixed models, which combine mental abilities with personality traits. According to advocates of ability models (Mayer \& Salovey, 1997), EI involves a set of interrelated capabilities that represent the intersection between cognitive and emotional abilities, differentiated from the personality and behavioural traits (empathy, assertiveness, communication, etc.) defended by the mixed models. These models have been widely applied by both the scientific and the business communities due to Goleman's $(1995,1998)$ particular interpretation of Salovey and Mayer's (1990) structure. However, further exploration is required from the marketing and consumer behaviour perspective (Kidwell et al., 2008, 2011).

According to the position defended by Mayer and Salovey (1997), consumer EI is defined as: "a person's ability to skilfully use emotional information to achieve a desired consumer outcome". Customers with high EI make flexible plans, organise memory and use information creatively, responding to a given complex situation in the most efficient way possible (Doucet et al., 2016; Sanz, 2002; Tsarenko \& Stizhakova, 2013). If emotions entail developing automatic reaction programmes with which to face genuinely difficult situations (Sanz, 2002), the importance of EI lies in learning how to 
manage these emotions so they work in the customer's favour, especially in difficult situations such as those experienced in the banking industry in recent years. The term EI describes aptitudes that compliment standard intelligence (Garaigordobil \& Oñederra, 2010; Klare et al., 2014), conceptualised through four basic abilities according to Mayer and Salovey (1997): (1) the perception, appraisal and expression of emotions (the ability to identify and recognise both one's own emotions and those of others); (2) emotional facilitation, use or assimilation (the capacity to take emotions into account in reasoning and conflict resolution processes); (3) understanding emotions (the ability to identify and distinguish between emotions, and to label and classify them); (4) emotional regulation (the capacity to manage and guide one's own and other people's emotions in an appropriate manner).

From the marketing perspective, EI consists of a series of abilities and competencies capable of motivating the customer to persevere in an endeavour despite possible frustrations, controlling impulses, and preventing anxiety from interfering in the faculties of empathy, relations and trust in others (Sanz, 2002). In recent years the Spanish banking sector has suffered greatly in an emotional environment that has led to a loss of credibility, with levels of trust in the sector falling by more than 20 percentage points from 76\% in 2011 to 54\% today (Inverco, 2016). Furthermore, Bennett and Kottasz (2012) argue that negative emotions such as anger have characterised customer perceptions of the banking sector's behaviour during the crisis period. In this vein, the literature has associated emotion management -EI- with the capacity for perception, action and relation with the environment (Sanz, 2002), particularly in complex situations such as the one the banking sector recently experienced.

Despite the importance of emotions, and their value in empowering not only employees but also customers, firms have traditionally pursued a functional engagement and have ignored the emotional aspects arising from service provision, forgetting that emotions are essential impulses which guide behaviour by either attracting the customer to a product or service, or driving them away (Matos \& San Martín, 2012). In this vein, Marinkovic and Obradovic (2015) find that many banks, in their attempts to retain and cultivate loyal customers, focus on introducing new products and services even though experience teaches that customers value intangible, emotional elements more positively, which they associate directly with the quality of the service provision and satisfaction. In this vein, Smith (2006) highlights the 
importance of studying customers' emotional responses - especially in contexts of service failure and recovery - if the organisation wishes to survive.

In their relations with the firm (the bank), customers experience and manage various types of emotions (Machleit \& Eroglu, 2000) resulting from different causes: internal attributions or mood states (recent events have generated feelings of widespread despondency), external agents (the economic crisis and its consequences, for example), or causes attributed to other variables over which the firm/bank has a greater level of control (Bigné \& Andreu, 2004). This latter category includes causes derived from interaction with service providers or employees (Dube \& Menon, 2000; Lee \& Dubinsky, 2003; Shainesh, 2012) and environmental variables in the bank (Gilboa \& Rafaeli, 2003; Shainesh, 2012; Sierra et al., 2000). Bank customers may therefore have negative feelings when service providers appear aggressive or do not speak frankly, and in contrast, they may experience positive emotions when employees are friendly, sincere and empathetic. Recall that the numerous mergers and takeovers involved in the restructuring of the banking sector have had harmful effects both for employees (job losses, internal pressure, and so on), and for customers (problems caused by banks disappearing, fewer branches, among others), and these will likely have major consequences on customer behaviour (Monferrer et al., 2016; Sanchis, 2013). In addition, environmental variables (music, lighting), design (layout, space), social aspects (contact with other customers) and other factors (waiting time and time devoted to the service provision, memory of previous experiences, etc.) should also be taken into account since they influence emotions, which in turn affect customer behaviour (Bigné \& Andreu, 2004; Lee \& Dubinsky, 2003).

In this context customers use the emotional information they compile to evaluate, through EI, the service favourably or otherwise (Matos \& San Martín, 2012; Pérez \& Rodríguez, 2015), and this information plays an essential role in how customers evaluate their satisfaction (Dube \& Menon, 2000; Ladhari, 2007; Maguire \& Geiger, 2015), trust (Morgan \& Hunt, 1994) and subsequent loyalty to the bank (White, 2006). Bearing in mind that achieving customer satisfaction is an important variable for firms' success (Sparks \& McColl, 2001; Kau \& Loh, 2006), an understanding of its affective and cognitive antecedents is essential to operate to maximum effect in the market. However, few studies have analysed the affective antecedents of satisfaction and relationship quality in situations of service failure and recovery (Chebat \& 
Slusarczyk, 2005; Schoefer \& Ennew, 2005). For this reason it is necessary to study and determine the effects of bank sector customers' emotional management (Smith \& Bolton, 2002).

Understanding the system by which emotions are processed (the study of EI) will extend our knowledge about bank customers, helping to comprehend the essence of their emotional impulses, providing a way to stimulate positive emotions, thus leading to greater satisfaction and loyalty to the bank and improving the relationship (Emo Insights International, 2015; Kidwell et al., 2008). This leads us to our first hypothesis:

$\mathrm{H}_{1}$ : Customers' EI is positively related to their perception of the quality of their relationship with the bank during the banking crisis.

\subsection{Relationship quality}

Relationship quality expresses the overall character of an exchange relationship between individuals (Henning et al., 2002; Moliner et al., 2007a; Moliner, 2009; Ulaga \& Eggert, 2006). Recent studies agree that customer satisfaction with the supplier's performance, trust in the supplier organisation and customer commitment are the key variables underlying relationship quality (Arfaeian et al., 2013; Moliner et al., 2007b, c, d; Ulaga \& Eggert, 2006). This theoretical approach takes into account three indicators in customers' evaluations of the quality of their relationship with the bank: satisfaction, trust and level of commitment (loyalty) (Moliner et al., 2007b, c, d; Monferrer et al., 2016; Roberts et al., 2003; Sánchez et al., 2007; Segarra et al., 2013; Ulaga \& Eggert, 2006).

Woodside et al., (1989) posited that satisfaction refers to the degree to which a person likes or dislikes a service or product after consuming it, or that it is a reaction to the difference between people's expectations of a product or service and the performance they perceive it to provide (Kwok et al., 2016; Oliver, 1981). Underlying the comparison between expectation and performance is what Woodruff and Gardial (1996) first described as the "expectancy-disconfirmation model" (Hoffman \& Bateson, 2011). When performance lives up to expectations, the expectation is confirmed and the consumer feels satisfied. However, lower (higher) perceived performance than the expectation leads to a negative (positive) disconfirmation (Fullerton \& Taylor, 2015; Sharifi \& Esfidani, 2014). When perceived performance exceeds expectations, it 
generally causes positive disconfirmation and satisfied customers, but negative disconfirmation generally leads to customer dissatisfaction because the perceived performance does not live up to their expectations. Olorunniwo et al. (2006) conceptualised customer satisfaction as a customer's post-experience fulfilment response.

Trust, in turn, has been defined as: "an individual's general expectation of whether he or she can rely on the word of another" (Guinaliu \& Jordán, 2016; Rotter, 1967). Trust means that an organisation's (bank's) good intentions are not questioned by its customers and that communication between the two parties is honest (Czepiel, 1990). Trust is generally understood to consist of three main dimensions: credibility (belief that the bank has the capability and experience to fulfil its promises to the customer), integrity (belief that the bank is guided by certain values, that it will keep its promise and that it has the capacity to do so), and benevolence (think that the bank is concerned for its customers' welfare) (Moliner et al., 2007b, c, d; Roberts et al., 2003). Trust is very important in circumstances where an individual has access to only partial, incomplete or ambiguous information (Hawes et al., 1989). In such situations, like those experienced in the banking sector in recent years, trust becomes a resource that can reduce information asymmetry (Matos \& San Martín, 2012; Moorman et al., 1993; Doney \& Cannon, 1997), facilitate decision making in risky situations (Mayer et al., 1995) and lessen the complexity associated with the decision-making process (Barber, 1983). The greater the levels of customer trust the higher the customer's commitment to the bank (Kramer, 1999). Given that trust is the essential foundation for the credibility of these promises, and that loyalty depends intrinsically on banks' keeping their promises, trust is key to consolidating customer loyalty (Morgan \& Hunt, 1994).

Finally, loyalty has generally been understood from a multidimensional approach (Brandt, 2000; Day, 1969). Oliver (1999) conceptualised loyalty through three dimensions: one linked to intentionality (conative loyalty), another related to its behavioural nature (action loyalty) and the third related to preference (cognition or liking). From the conative view, loyalty is understood as customers' repeated purchase from the company or service provider (bank) (Bass, 1974; Fournier, 1998) and is responsible for improving the relationship between the two parties (Yi, 1990). From the attitudinal view, loyalty is understood as a feeling of attachment to the service or company (Hallowell, 1996). Finally, the cognitive view of loyalty encompasses the two previous approaches and focuses on brand outcomes (Segarra, 2007). Gremler and 
Brown (1996) define loyalty as: "the degree to which a customer exhibits repeat purchasing behavior from a service provider, possesses a positive attitudinal disposition toward the provider, and considers using only this provider when a need for this service arises". In summary, loyalty is defined as: "the customer's intention to continue his or her relationship with the bank" (Monferrer et al., 2016).

Having defined the variables of relationship quality, it is important to comment that these indicators are different, but causally related (Anderson \& Srinivasan, 2003; Bloemer \& Odekerken, 2002; Moliner et al., 2007b, c, d; Ulaga \& Eggert, 2006). The study of customer satisfaction is, therefore, of great importance in the reseach because of its effect on trust and loyalty (Karatepe \& Tekinkus, 2006; Kashif et al., 2015; Sayani, 2015; Szymanski \& Henard, 2001). Therefore, we propose that:

$\mathrm{H}_{2}$ : Customers' satisfaction with the bank positively influences their trust during the banking crisis.

Satisfaction is considered to be an antecedent of customer loyalty behaviour (Aksoy, 2014; Amin, 2016; Kashif et al., 2015; Kaura et al., 2015; Sayani, 2015). Customers' lifetime loyalty to a service depends heavily on their satisfaction with the service offered (Kashif et al., 2015; Ndubisi, 2007). Hence, in loyalty research the satisfaction construct is conceptualised as cumulative satisfaction, rather than a transaction-specific satisfaction judgement (Harris \& Goode, 2004). Parasuraman et al. (1994) argue that overall satisfaction is relatively more stable than transaction-specific satisfaction. Offering their customers continued satisfaction therefore allows the bank to maintain and nurture long-term relationships and improve customer profitability and attachment (Kaura \& Datta, 2012; Fuentes et al., 2014). Therefore, we propose that:

$\mathrm{H}_{3}$ : Customers' satisfaction with the bank positively influences their loyalty during the banking crisis.

Finally, the literature finds a positive relationship between banks whose customer relationships are grounded on the principles of credibility, integrity and benevolence, and customer retention (Kaura et al., 2015). If customers' trust levels are high, they will be prepared to undergo certain short-term sacrifices (as has frequently happened in the current context) because they consider that cooperation with a given 
company can bring them numerous benefits in the long run (Marinkovic \& Obradovic, 2015). Generating trust has an impact on creating loyalty and, therefore, on customers' intention to repurchase and to continue in the relationship (Dimitriadis et al., 2011; Pérez \& Rodríguez, 2015; Shainesh, 2012; Trif, 2013). Therefore we posit that:

$\mathrm{H}_{4}$ : Customers' trust in the bank has a positive influence on their loyalty during the banking crisis.

-Fig. 1-

\section{Methodology}

\subsection{Data collection and sample}

The research team signed an agreement with a major Spanish bank (one of the top six firms based on total assets according to Moody's international rating agency). As a result of this agreement we were able to interview customers from their branches for this study, which was carried out in four Spanish provinces: Castellón, Valencia, Alicante and Murcia.

Before beginning the fieldwork, in the last quarter of 2015 the questionnaire items were examined by banking experts and pre-tested on a group of 25 customers. This procedure helped to improve the wording of some of the questionnaire items, and ensured the appropriate form, layout, sequence difficulty, length, and completion time for the questionnaires. Following this review, customers were interviewed by a team of researchers in the field during the first quarter of 2016. To prevent significant interviewer effect in the results we followed Hox's (1994) recommendation to use the Kish (1962) intraclass correlation coefficient (ICC). Our results were close to 0.031, as recommended by the literature for face-to-face surveys (Groves, 2004; Davis et al., 2010; Tortosa et al., 2015).

The research team interviewed customers while they were waiting to be attended, and only regular customers of the branch were included in the sample. Interviews were used rather than self-completion in order to avoid question misinterpretations. The results were aggregated, thereby assuring confidentiality in the dissemination of the results.

The criterion for the fieldwork was to conduct five customer interviews for each of the branches analysed. Then, of the 530 branches in the area studied, our final study 
sample consisted of 1125 customers from 225 offices (five customers per office). This customer sample covered 42.45 per cent of all the branches in the geographical areas analysed, with a balanced percentage of responses obtained in each of these regions.

Representation of different branch types was also guaranteed by following criteria such as number of employees per branch (the average number was between five and six; $59.2 \%$ of the branches had between two and five employees and $41.8 \%$ more than five employees) or the classification of the branch according to the internal criteria of the bank (28.1\% were firmly established branches, $32.4 \%$ were in small locations, $14.8 \%$ were in medium-sized locations, $13.8 \%$ were in urban locations and $10.7 \%$ were branches for foreign customers).

In sum, as is shown in Table 1, the sample consisted of 540 women (48\%) and 585 men (52\%), with an average age of 47 (between 18 and 29 years 15\%; between 30 and 39 years 20\%; between 40 and 49 years $21 \%$; between 50 and 59 years 19\%; between 60 and 69 years 14\%). These profiles were comparable to the total population of customers in the branches analysed.

\section{-Table 1-}

\subsection{Measurement instruments}

The scale proposed by Tsarenko and Strizhakova (2013) was adapted to the bank branch context to measure the EI of the bank's customers. These authors adapted the initial scale designed by Brackett et al. (2006). This multidimensional scale conceives EI as based on five dimensions associated with individuals' emotional abilities: perception, use, understanding, emotional management and social management.

We used an adapted version of the scale by Bloemer and Odekerken (2002) to measure satisfaction, and that of Camarero et al. (2005) to measure trust and loyalty.

All the questionnaire items were evaluated on a five-point Likert scale where $1=$ totally disagree and $5=$ totally agree (see Table 2 ).

\subsection{Validity and scale reliability}

Confirmatory factor analysis (CFA) was run using the structural equation model (SEM) technique to refine the scales with version 6.1 of the EQS multivariate software package. The parameters were estimated using the maximum likelihood approach. 
First, we checked for signs of multicollinearity by testing the variance inflation factor (VIF) among latent variables in our proposed overall model. Values were below 10 (Myers, 1990; Hair et al., 2009), suggesting multicollinearity was not an issue in our study. Secondly, a t-test of independent means was performed on the different dimensions of the variables in the proposed model. This test was conducted using the first 45 and last 45 respondents. No significant differences were found between these respondents at the 0.05 level, indicating an absence of non-response bias (Armstrong \& Overton, 1977). Thirdly, to rule out common method data collection bias we performed a one-factor test among latent variables in the proposed model (Podsakoff et al., 2003; Friedrich et al., 2009). The overall fit was significantly poorer than the results of the CFA with the study's proposed factor structure. These results imply that a single factor poorly reflects the data, suggesting the absence of any common method bias in collecting the data (Farrell \& Oczkowski, 2009). Additionally, several ANOVA were run to confirm that sample characteristics do not affect the model constructs. The control variables were customer's bank, location, age, occupation, education level and income level. Results revealed no significant differences in any of the analyses.

We then followed a "model development strategy" (Hair et al., 2009). Based on latent variable structures assumed for the different constructs, we perfected the initial models by suppressing the least appropriate indicators. Taking Jöreskog and Sörbom (1993) as a reference, first we examined the estimation parameters. Indicators that did not satisfy the strong convergence condition, with individual standardised coefficients ( $\lambda$ ) under 0.6 were withdrawn (Bagozzi \& Youjae, 1988; Hair et al., 2009). Compliance with the weak convergence condition was then verified (Steenkamp \& Van Trijp, 1991) by analysing the significance of the factor regression coefficients between indicators and their corresponding latent variables. This was done by imposing the maximum requirement on the Student $\mathrm{t}$ value $(\mathrm{t}>2.58 ; \mathrm{P}=0.01)$. Following this process three indicators were removed: SAT.3 from the satisfaction scale, TRU.5 from the trust scale and LOY.3 from the loyalty scale. Finally, evolution of the main model fit measurements was monitored as the indicators were removed. The fit of the conceptual model to the empirical data was assessed with $\chi^{2}$ statistics, the normed fit index (NFI), the non-normed fit index (NNFI), the incremental fit index (IFI), the comparative fit index (CFI), the goodness-of-fit index (GFI), the average goodness-of-fit index (AGFI), the root mean square residual (RMR) and the root mean square of approximation (RMSEA). 
Several tests were then run to verify whether the above refinement process had affected scale reliability. These tests were internal consistency through Cronbach's alpha $(\alpha>0.7)$, composed reliability of the construct $(C R>0.7)$ and analysis of variance extracted (AVE>0.5) (Churchill, 1979; Nunnally, 1979; Fornell \& Lacker, 1981). The correlations were relatively high and significant and therefore provided sufficient guarantee of convergent validity. A summary of the results after factor and reliability tests is shown in Table 2 .

\section{-Table 2-}

Next, we analysed convergent and discriminant validity. Convergent validity was verified by returning to the confirmatory factor analysis performed at the start of the process and observing the estimated value and significance of the correlations between the dimensions in the scales. Table 3 shows the discriminant validity of the constructs considered, evaluated through AVE (Fornell \& Larcker, 1981). When the square root of the AVE between each pair of factors is higher than the estimated correlation between those factors, as occurs here, discriminant validity is ratified.

-Table 3-

\section{Results}

As with the validation of the scales, the hypotheses were tested using SEM with version 6.1 of the EQS multivariate software package. Table 4 shows that all the hypotheses are confirmed and present optimal model fit measurements.

\section{-Table 4-}

Therefore, the results confirm the influence of customers' EI on the quality of the relationship they have with their banks. Specifically, this influence is determined primarily by the positive and significant relationship with the degree of satisfaction shown by the bank's customers, thus confirming our first research hypothesis $(\mathrm{H} 1: \lambda=$ $0.423 ; \mathrm{t}=9.269)$. A deeper look at the results for the interrelationships between the variables of relationship quality shows the direct influence of customer satisfaction on trust $(\mathrm{H} 2: \lambda=0.796 ; \mathrm{t}=27.379)$ and customer loyalty to the bank $(\mathrm{H} 3: \lambda=0.181 ; \mathrm{t}=$ 4.389). Finally, although a direct effect of satisfaction on loyalty was demonstrated, the 
results show that this relationship is strengthened even more through the indirect influence on loyalty and through the mediating effect of trust, therefore confirming our final hypothesis $(\mathrm{H} 4: \lambda=0.627 ; \mathrm{t}=14.322)$.

\section{Discussion and implications}

The objective of this study was to highlight the central role of customers' management of emotions through their EI on the perception of relationship quality offered by the Spanish banking sector in the context of crisis. The study focused on a complex organization with a uniform strategy, but which attends the public in different centers (bank branches). This context allowed us to isolate the effect of the general marketing strategy from the effects of actions at the branch level, thereby capturing relational marketing factors at the micro level. Sobre esta base, from the academic point of view, podemos identificar distintas contribuciones derivadas del presente trabajo.

En primer lugar, the originality of this study lies in proposing a theoretical model that, from a microeconomic level, integrates psychological variables such as customers' EI with more traditional relational marketing research variables (satisfaction, trust and loyalty) that have been severely challenged in the context of the banking crisis. Effectively, the crisis situation that recently engulfed the Spanish banking sector exposed the need for banks to redirect their business strategies and build high quality commercial relationships. In this context, the purchaser-supplier relationship needs to become a fundamental research topic since the appropriate strategic management of this relationship can be turned into a competitive advantage for the firm (O'Toole \& Donaldson, 2002). Achieving positive customer emotions in a sector that has been closely associated with negative emotions in recent years (Bravo et al., 2010; Bennett \& Kottask, 2012; Monferrer et al., 2016) should be taken as a reference for improving perceptions about the bank. To this end, effective strategies should be introduced that can channel emotions in an attempt to overcome the conflictive circumstances customers have experienced, and therefore positively affect their trust and improve their perception of the quality of their relationship with the bank (Bennett \& Kottasz, 2012; Monferrer et al., 2016). In fact, in a recent study Marinkovic and Obradovic (2015) state that customers' emotional responses should be studied to attain quality relationships, especially in contexts of service failure and recovery. Indeed, some companies (including banks) are discovering that maximising emotional performance, that is, 
appropriate emotional management, opens up a significant opportunity for business differentiation, especially in a context where emotions are typically ignored (Heffernan \& LaValle, 2007; Zárate \& Matviuk, 2010).

Second, and more specifically, the study advances research on the emotional bonds between customer and firm by identifying a key variable: customer IE. The results of this study confirm the close relationship between customers' EI and the macro-construct of relationship quality. This causal relationship is verified for the first time in the literature and, from the experiential marketing perspective, strengthens the idea that customer emotions play a very relevant role in explaining relational behaviors, and consequently corporate marketing strategy must be accompanied by careful attention to service experiences at the branch or front office level.

In order to have satisfied customers banks should try to build strong emotional bonds with their customers, and to do so, they obtain higher levels of trust and loyalty. A este respecto it is important to be aware not only of emotions but also of how they work, to what extent each customer's EI can affect his or her perception of the relationship quality, and from there, design marketing strategies adapted to the results in each case. However, introducing measurement instruments to evaluate each individual customer's EI in order to design tailor-made strategies may prove too complicated a strategy in the day-to-day running of the bank. Given the role of emotions in evaluating service, it would seem more realistic for the bank to design actions that, in general, and without ignoring pertinant tangible aspects, could highlight the more emotional aspects of service provision. It should be remembered that regaining customer trust involves reconstructing emotions in the relationship, is even more pertinent in a sector like banking which is still immersed in a process of change (Ariza et al., 2013; Gorroño, 2008). Indeed, from an experiential marketing approach, moment of truth takes on a decisive role in managing customers' expectations in the right way and consolidating the business relationship since, depending on the customer's emotional response, it enables the bank to be more attuned to the customer, and the resulting enhanced adaptation to his or her expectations (Maguire \& Geiger, 2015; Pansari \& Kumar, 2017).

Consequently banks should design scenarios and procedures that generate positive emotions in their customers. Bank employees are of prime importance because they are responsible for direct contact with the customer, they are the main source of information and they assess the customers' needs and perceive their emotional states 
(Guenzi \& Georges, 2010; Marinkovic \& Obradovic, 2015). Hence, good EI training would allow employees to adapt to their customers, thereby rebuilding lost trust, enhancing the quality of their interpersonal relationships (Anand \& Udayasuritan, 2010; Ariza et al., 2013; Wong et al., 2007; Zárate \& Matviuk, 2010).

In parallel, achieving an enhanced customer perception of relationship quality involves considerable effort in environmental variables (music, lighting, temperature), design (colour, layout, space, complexity), social factors (contact with other customers, word-of-mouth) and additional factors (waiting time and the time devoted to the service provision, memories, etc.) that play an influential role on the emotions the customer is feeling and their attitude to the bank (Bigné \& Andreu, 2004; Lee \& Dubinsky, 2003).

All these measures involve rethinking marketing policies to focus on more emotional aspects. This is in the line of many studies which recommend that banks should steer their marketing efforts toward intangible variables that enable them to strengthen positive client behaviors and attitudes toward them (Adamson et al., 2003; Arbore \& Busacca, 2009; Khan et al., 2016; Marinkovic \& Obradovic, 2015; Moorthi \& Mohan, 2017; Sayani, 2015). In this line, the banking sector is currently giving greater priority to repairing and building sustainable bonds with its customers, thus generating a kind of emotional attachment due to the guiding paradigm of relationship marketing (Khan et al., 2016; Levy \& Hino, 2016; Monferrer et al., 2016).

Thirdly, the study contributes by identifying la interrelación existente entre las tres variables fundamentales que conforman the macro-construct of relationship quality, made up of satisfaction, trust and loyalty. Then the approach to the construct of relationship quality defended in recent works has been confirmed (Moliner et al., 2007b, c, d; Monferrer et al., 2016; Segarra et al., 2013; Ulaga \& Eggert, 2006), advocating consideration of three related variables: satisfaction, trust and loyalty. In particular, satisfaction acts as an antecedent of trust and both in turn lead to greater customer loyalty.

Finally, the fourth contribution refers to the sample of commercial bank users to test the causal model, following the recommendation by some authors to study cases involving non-luxury (Roy \& Rabbanee, 2015) and non-leisure (Kaura et al., 2015) firms. This study goes further by examining the customer-branch relationship within the same bank. In doing so, we highlight the role customer emotional experiences and interactions in the branch play in strengthening their positive and sustainable 
relationship. In this context, where the influence of corporate policies is limited, customer IE is crucial to explaining customer-branch relationship quality.

\section{Managerial implications}

Because of the crisis, junto con the current technological revolution en la que la banca está inmersa, many banks have implemented aggressive cost-cutting strategies in order to survive, such as staff restructuring, branch closures and promoting online banking over face-to-face personal attention. In fact, according to Garrido (2016), between 2008 and 2014, 29.000 branches were closed in the Eurozone with a loss of over 200.000 jobs. The results of this study, however, show that identifying, understanding and managing emotions have a significant role in developing relationship quality. Therefore, from the position of recommendations for managers, the Spanish banking sector need to ask what the effect of this new landscape might be on customer relationship quality. Emotional bonds tend to arise out of personal relationships between contact personnel and customers. If these interactions are reduced to a minimum, the firm-customer link will be essentially a rational one, leaving a strategic flank open to attack by competitors. In this new landscape managers should find new channels through which to foster emotional bonds with customers in order to generate the positive experiences that lead to customer relationship quality.

Banks managers would be advised to turn its attention to more emotional aspects of its service in the interest of efficient emotional management (Hatch et al., 2003; Hau and Tuy, 2012; Lin and Liang, 2011; Verleye, 2015). El presente estudio se sumaría a las llamadas realizadas recientemente por otros autores en este sentido, como Monferrer et al. (2016) and Sanchis (2013), pointing to the need to develop a new type of bank that is more emotional, less speculative, more social and more transparent; only in this way will a more positive emotional environment be generated in which a significant margin of trust will once again be established in their relationships. For this reason banks should design physical spaces with an atmosphere that will have a positive impact on their customers, and pay particular attention to interactions with contact personnel and other customers present at that moment of truth.

International banks such as Banco Santander, BBVA and Caixa Bank seem to be taking a determined stance to renovate by introducing a two-pronged strategy for 
establishing and strengthening customer relations: providing a face-to-face service based on generating positive experiences and emotions, and promoting multiple channels. In fact these banks are currently immersed in a process of radical renovation of the traditional concept of the branch with its simple aesthetic and predictable service, both of which are now outdated. The new concept of the branch currently being introduced looks to the future, transforming it into a place to attend to and advise customers, and which will become a central focus to encourage and facilitate a more personal and enduring relationship. This transformation includes longer opening hours and a concept that appears to draw from the store model. Its design is more accessible, more agile, more welcoming and more digital, conceived to attract the customer's attention from the first moment. The bank is made to look inviting from the outside. Inside, the premises will be equipped with hearing loops for people with impaired hearing, accessible ATMs and information in braille. The premises will also be more efficient and sustainable, with no architectural barriers and smart heating, air conditioning and lighting systems. Furniture will be more flexible and used to create open spaces in innovative layouts, providing conversation areas, meeting rooms and work spaces that encourage communication between the bank's staff and its customers. Needless to say, these branches of the future will be more technological with LED display screens, tablets, virtual and remote consultants, and interactive window displays.

This new strategy based on a commitment to experiential and emotional marketing, chiming with the results obtained in this study, will allow banks to be even closer and more connected to their customers and strengthen their relationship with them, and to enhance their service quality and excellence, the keystones of any business.

\section{Limitations and future research}

This study is not without certain limitations that should be taken into account when appraising the above conclusions. These same limitations lead us to propose possible lines for future research.

First, the unit of analysis in this study is limited to the Spanish bank sector. Future research could usefully make comparisons with other service sectors. New studies might also test the relationships posited in other international contexts, which would favour the generalisation of our results.

Second, the study sample comprised only customers who had experience with the financial services of a specific bank. Therefore, caution is warranted when 
generalising the results to potential customers who have no experience with this financial brand.

Third, the use of transversal data, as is the case here, may be seen as a limitation when drawing causal inferences. Future studies could explore the relationships posited using longitudinal data as well as proposing complementary qualitative methods.

Finally, our model represents a specific reference contribution on the basis of which new effects can be proposed through the consideration of new factors. Future research may also consider amd compare the influence of EI in the online environment. A growing percentage of the population uses no face-to-face banking services, carrying out all their transactions on line instead. This is a fascinating landscape from the relationship quality perspective, but it raises new challenges for emotional marketing.

Another topic for future study, in light of the traditional consideration of EI from the employee perspective, is to examine employee and customer emotional influences jointly.

Analysing the causal model in terms of customer age would also be a useful line of study, assuming that millennials and seniors will behave differently, which could have important repercussions for marketing strategies.

A final research suggestion would be to introduce new non-transactional and emotional variables that determine relationship quality, such as the WOM effect, customer engagement, advocacy or self-brand connection, together with the marketing outcomes contemplated (satisfaction, trust and loyalty).

\section{References}

Abraham, R. (2000). The role of job control as a moderator of emotional dissonance and emotional intelligence - Outcome relationships. The Journal of Psychology, 134 (2), 169-184.

Aksoy, L. (2014). Linking satisfaction to share of deposits: An application of the Wallet Allocation Rule. International Journal of Bank Marketing, 32 (1), 28-42.

Amin, M. (2016). Internet banking service quality and its implication on e-customer satisfaction and e-customer loyalty. International Journal of Bank Marketing, 34 (3), 280-307. 
Anand, R., \& UdayaSuriyan, G. (2010). Emotional Intelligence and its relationship with leadership practices. International Journal of Business and Management, 5 (2), $65-76$.

Anderson, R.E., \& Srinivasan, S.S. (2003). E-Satisfaction and E-Loyalty: A contingency framework. Psychology and Marketing, 20 (2), 123-138.

Arbore, A. \& Busacca, B. (2009). Customer satisfaction and dissatisfaction in retail banking: exploring the asymmetric impact of attribute performances. Journal of Retailing and Consumer Services, 16 (4), 271-280.

Arfaeian, A., Ghorbanifard, B., Mousavi, S., \& Aziziha, H. (2013). Investigating personal characteristics on e-banking adoption. Management Science Letters, 3 (12), 2939-2944.

Ariza, J.A., Lucia, A.M., \& Morales-Gutiérrez, A.C. (2013). La implicación emocional de los empleados de banca en Europa. Universia Business Review, 38, 32-49.

Armstrong, J.S., \& Overton, T.S. (1977). Estimating nonresponse bias in mail surveys. Journal of Marketing Research, 14, 396-402.

Bagozzi, R.P., \& Youjae, Y. (1988). On the evaluation of structural equation models. Journal of the Academy of Marketing Science, 16 (Spring), 74-94.

Bapat, D. (2017). Exploring the antecedents of loyalty in the context of multi-channel banking. International Journal of bank Marketing, 35 (2), 174-186.

Barber, B. (1983). The logic and limits of trust. New Brunswick, NJ: Rutgers University Press.

Bass, F.M. (1974). The theory of stochastic preference and brand switching. Journal of Marketing Research, 11, 1-20.

Bekaert, G., Ehrmann, M., Fratzscher, M., \& Mehl, A. (2014). The global crisis and equity market contagion. The Journal of Finance, 69 (6), 2597-2649.

Bennett, R., \& Kottasz, R. (2012). Public attitudes toward the UK banking industry following the global financial crisis. International Journal of Bank, 30 (2), 128147. 
Bigné, E., \& Andreu, L. (2004). Emociones, satisfacción y lealtad del consumidor en entornos comerciales. Un análisis comparativo entre centro comercial y centro urbano. Distribución y Consumo, julio-agosto, 77-87.

Bloemer, J., \& Odekerken G. (2002). Store satisfaction and store loyalty explained by customer- and store-related factors. Journal of Customer Satisfaction, Dissatisfaction and Complaining Behavior, 15, 68-80.

Brackett, M.A., Rivers, S.E., Shiffman, S., Lerner, N., \& Salovey, P. (2006). Relating emotional abilities to social functioning: A comparison of self-report and performance measures of emotional intelligence. Journal of Personality and Social Psychology, 91 (4), 780-95.

Brandt, R. (2000). Loyalty really isn't all that simple, restrictive. Marketing News, 34 (17), 7.

Bravo, R., Matute, J., \& Pina, J.M. (2010). Las asociaciones de la imagen como determinantes de la satisfacción en el sector bancario español. Cuadernos de Economía y Dirección de la Empresa, 43, 9-36.

Camarero, M.C., Gutiérrez, J., \& San Martín, S. (2005). The impact of customer relationship marketing on the firm performance: A Spanish case. Journal of Services Marketing, 19 (4), 234-244.

Chebat, J.C., \& Slusarczyk, W. (2005). How emotions mediate the effects of perceived justice on loyalty in service recovery situations: An empirical study. Journal of Business Research, 58, 664-673.

Cherniss, C. (2001). Emotional intelligence and organizational effectiveness. In C. Cherniss \& D. Goleman (Eds.), The emotionally intelligent workplace (pp. 312). San Francisco: Jossey Bass.

Chiva, R., \& Habib, J. (2015). A frameword for organizational learning: Zero, adaptive and generative learning. Journal of Management \& Organization, March, 1-19.

Churchill, G. A. Jr. (1979). A paradigm for developing better measures in marketing. Journal of Marketing Research, 16, 64-73.

Czepiel, J.A. (1990). Service encounters and service relationships: Implications for Research. Journal of Business Research, 20 (1), 13-21. 
Davis, R.E., Couper, M.P., Janz, N.K., Caldwell, C.H., \& Resnicow, K. (2010). Interviewer effects in public health surveys. Health Education Research, 25 (1), 14-26.

Day, G.S. (1969). A two dimensional concept of brand loyalty. Journal of Advertising Research, 9, 29-36.

Deeter, D.R., \& Sojka, J.Z. (2003). Developing effective salespeople: Exploring the link between emotional intelligence and sales performance. International Journal of Organizational Analysis, 11 (3), 211-20.

Devlin, J.F., \& Azhar, S. (2004). Life would be a lot easier if we were a Kit Kat: Practitioners' views on the challenges of branding financial services successfully. Journal of Brand Management, 12 (1), 12-30.

Dimitriadis, S., Kouremenos, A., \& Kyrezis, N. (2011). Trust-based segmentation: Preliminary evidence from technology-enabled bank channels. International Journal of Bank Marketing, 29 (1), 5-31.

Doney, P.M., \& Cannon, J.P. (1997). An Examination of the nature of trust in buyerseller relationships. Journal of Marketing, 61 (2), 35.

Doucet, L., Wang, B.S.L., \& Oldham, G.R. (2016). I know how you feel, but it does not always help: Integrating emotion recognition, agreeableness, and cognitive ability in a compensatory model of service performance. Journal of Service Management, 27 (3), 1-36.

Dube, L., \& Menon, K. (2000). Multiple roles of consumption emotions in postpurchase satisfaction with extended service transactions. International Journal of Service Industry Management, 11 (3), 287-304.

Emo Insights International (2015). Primer estudio de gestión emocional feeling experience management en el mercado bancario de particulares en España. Madrid: Emo Metrics Consulting.

Farrell, M.A., \& Oczkowski, E. (2009). Service worker customer orientation, organisation/job fit and perceived organisational support. Journal of Strategic Marketing, 17 (2), 149-167. 
Fornell, C., \& Larcker, D.F. (1981). Evaluating structural equation models with unobservable variables and measurement error. Journal of Marketing Research, $18,39-50$.

Fournier, S. (1998). Consumers and their brands: Developing relationship theory in consumer research. Journal of Consumer Research, 24, 343-373.

Friedrich, T.L., Byrne, C.L., \& Mumford, M.D. (2009). Methodological and theoretical considerations in survey research. The Leadership Quarterly, 20, 57-60.

Fuentes, M., Moliner, B., \& Gil, I. (2014). Effect of customer heterogenity on there relationship. Revista Española de Investigación de Marketing ESIC, 18, 78-92.

Fullerton, G., \& Taylor, S. (2015). Dissatisfaction and violation: Two distinct consequences of the wait experience. Journal of Service Theory and Practice, 25 (1), 31-50.

Garaigordobil, M., \& Oñederra, J.A. (2010). Inteligencia emocional en las víctimas de acoso escolar y en los agresores. European Journal of Education and Psychology, 3 (2), 243-256.

Garrido, A (2016). The Eurozone banking system: a sector undergoing transformation. Policy Brief (EuropeG), 8, 1-12.

Gijsenberg, M.J., Van Heerde, H.J., \& Verhoef, P.C. (2015). Losses loom longer than gains: Modeling the impact of service crises on perceived service quality over time. Journal of Marketing Research, 52 (5), 642-656.

Gilboa, S., \& Rafaeli, A. (2003). Store environment, emotions and approach behaviour: Applying environmental aesthetics to retailing. International Review of Retail, Distribution and Consumer Research, 13 (2), 195-211.

Goleman, D. (1995). Emotional intelligence. New York, N.Y: Batam Books.

Goleman, D. (1998). Working with emotional intelligence. New York, NY: Batam Books.

Gorroño, A.I. (2008). El abordaje de las emociones en las organizaciones: luces y sombras. Cuadernos de Relaciones Laborales, 26 (2), 139-157.

Gremler, D.D., \& Brown, S.W. (1996). Service loyalty: Its nature, importance, and implications. In Edvardsson, B., Brown, S.W. Johnston, R. \& Scheuing, E.E. 
(Eds.), Advancing Service Quality: A Global Perspective (pp. 171-80). New York, NY: International Service Quality Association.

Groves, R.M. (2004). Survey Errors and Survey Costs. Hoboken, NJ: John Wiley \& Sons.

Guenzi, P., \& Georges, L. (2010). Interpersonal trust in commercial realtionships: Antecedents and consequences of customer trust in the saleperson. European Journal of Marketing, 44 (1/2), 114-138.

Guinaliu, M., \& Jordán, P. (2016). Building trust in the leader of virtual teams. Spanish Journal of Marketing, ESIC, 20, 58-70.

Hair, J.F., Black, W.C., Babin, B.J., \& Anderson, R.E. (2009). Multivariate Data Analysis. Upper Saddle River, NJ.: Prentice Hall.

Hallowell, R. (1996). The relationships of customer satisfaction, customer loyalty and profitability: An empirical study. International Journal of Service Industry Management, 7(4), 27-42.

Hansen, T. (2014). The role of trust in financial customer-seller relationships before and after the financial crisis. Journal of Consumer Behaviour, 13, 442-452.

Harris, L.C., \& Goode, M.M.H. (2004). The four levels of loyalty and the pivotal role of trust: a study of online service dynamics. Journal of Retailing, 80 (2), 139-158.

Hatch, M.J.; Schultz, M., \& Williamson, J. (2003). Bringing the corporation into corporate branding. European Journal of Marketing, 37 (7/8), 1041-1064.

Hau, L.N., \& Thuy, P.N. (2012). Impact of service personal values on service value and customer loyalty: A cross-service industry study. Service Business, 6 (2), 137155.

Hawes, J.M., Mats, K.E., \& Swan, J.E. (1989). Trust earning perceptions of sellers and buyers. Journal of Personal Selling and Sales Management, 9, 1-8.

Heffernan, R., \& LaValle, S. (2007). Emotional interactions: The frontier of the customer-focused enterprise. Strategy \& Leadership, 35 (3), 38-49.

Heffernan, T., O’Neill, G., Travaglione, T., \& Droulers, M. (2008). Relationship marketing. The impact of emotional intelligence and trust on bank performance. International Journal of Bank Marketing, 26 (3), 183-199. 
Henning, T., Gwinner, K.P., \& Gremler, D.D. (2002). A Integration of Relational Benefits and Relationship Quality. Journal of Service Research, 4 (3), 230-247.

Higgs, M. (2004). A study of the relationship between emotional intelligence and performance in UK call centres. Journal of Managerial Psychology, 19 (4), 44254.

Hoffman, K.D., \& Bateson, J.E.G. (2011). Services Marketing: Concepts, Strategies, and Cases (4th ed.). Ohio: South-Western Cengage Learning.

Hox, J.J. (1994). Hierarchical regression models for interviewer and respondent effects. Sociological Methods \& Research, 22 (3), 300-318.

$\begin{array}{lllll}\text { Inverco (2016). Observatorio Inverso. } & \text { Retrieved }\end{array}$ htpp//www.observatorioinverco.com/.

Jöreskog, K., \& Söbom, D. (1993). LISREL 8: Structural equation modeling with the SIMPLIS command language. Chicago, Illinois: Scientific Software International.

Karatepe, O.M., \& Tekinkus, M. (2006). The effects of work-family conflict, emotional exhaustion, and intrinsic motivation on job outcomes of front-line employees. International Journal of Bank Marketing, 24 (3), 173-193.

Kashif, M., Shukran, S.S.W., \& Rehman, M.A. (2015). Customer satisfaction and loyalty in Malaysian Islamic Banks: A PAKSERV investigation. International Journal of Bank Marketing, 33 (1), 23-40.

Kau, A., \& Loh, E.W. (2006). The effects of service recovery on consumer satisfaction: A comparison between complainants and non-complainants. Journal of Services Marketing, 20 (2), 101-11.

Kaura, V., \& Datta, S.K. (2012). Impact of service quality on satisfaction in the Indian banking sector. The IUP Journal of Marketing Management, 11 (3), 38-47.

Kaura, V., Prasad, D., \& Sharma, S. (2015). Service quality, service convenience, price and fairness, customer loyalty, and the mediating role of customer satisfaction. International Journal of Bank Marketing, 33 (4), 404-422. 
Khan, I., Rahman, Z. \& Fatma, M. (2016). The role of customer brand engagement and brand experience in online banking. International Journal of Bank Marketing, 34 (7), 1025-1041.

Kidwell, B., Hardesty, D.M., \& Childers, T.L. (2008). Consumer emotional intelligence: Conceptualization, measurement, and the prediction of consumer decision making. Journal of Consumer Research, 35 (1), 154-166.

Kidwell, B., Hardesty, D.M., Murtha, B.R., \& Sheng, S. (2011). Emotional intelligence in marketing exchanges. Journal of Marketing, 75 (1), 78-95.

Kish, L. (1962). Studies of interviewer variance for attitudinal variables. Journal of the American Statistical Association, 57, 92-115.

Klare, D., Behney, M., \& Ferrer, B. (2014). Emotional intelligence in a stupid world. Library Hi Tech News, 31 (6), 21-24.

Kramer, R.M. (1999). Trust and distrust in organizations: Emerging perspectives, enduring questions. Annual Review of Psychology, 50, 569-598.

Kwok, S.Y., Jusoh, A., \& Khalifah, Z. (2016). The influence of service quality on satisfaction: Does gender really matter? Intangible Capital, 12 (2), 444-461.

Ladhari, R. (2007). The effect of consumption emotions on satisfaction and word-of mouth communications. Psychology and Marketing, 24 (1), 1085-1108.

Lee, S., \& Dubinsky, A.J. (2003). Influence of salesperson characteristics and customer emotion on retail dyadic relationships. International Review of Retail, Distribution and Consumer Research, 13 (1), 21-36.

Levy, S. \& Hino, H. (2016). Emotional brand attachment: a factor in customer-bank relationships. International Journal of Bank Marketing, 34 (2), 136-150.

Lin, J.S.C., \& Liang, H.Y., (2011). The influence of service environments on customer emotion and service outcomes. Managing Service Quality: An International Journal, 21 (4), 350-372.

Machleit, K.A., \& Eroglu, S.A. (2000). Describing and measuring emotional response to shopping experience. Journal of Business Research, 49 (2), 101-111. 
Maguire, L., \& Geiger, S. (2015). Emotional timescapes: The temporal perspective and consumption emotions in services. Journal of Services Marketing, 29(3), 211223.

Marketing Science Institute (2014). Research Priorities 2014-2016. Cambridge, Mass.: Marketing Science Institute.

Marketing Science Institute (2016). Research Priorities 2016-2018. Cambridge, Mass.: Marketing Science Institute.

Marinkovic, V., \& Obradovic, V. (2015). Customers'emotional reactions in the banking industry. International Journal of Bank Marketing, 33 (3), 243-260.

Matos, R.F., \& San Martín, S. (2012). Análisis sobre la reputación de marca, las emociones y la confianza como formadoras de la satisfacción del turista. Contaduría y Administración, 57 (4), 253-286.

Mayer, R.C., Davis J. H., \& Shoorman, F. D. (1995). An integrative model of organizational trust. Academy of Management Review, 20 (3), 709-734.

Mayer, J., Roberts, R. \& Barsade, S. (2008). Human abilities: Emotional Intelligence. Annual Review of Psychology, 59, 507-536.

Mayer, J.D., \& Salovey, P. (1997). What is emotional intelligence? In Salovey, P. \& Sluyter D. (Eds.), Emotional development and emotional intelligence: Implications for educators (pp. 3-34). New York: Harper Collins.

Ministerio de Economía, Industria y Competitividad (MINECO, 2017). Estrategia Española de Ciencia y Tecnología y de Innovación para el periodo 2013-2020. Retrieved from http://www.idi.mineco.gob.es

Moliner, M.A., Sánchez, J., Rodríguez, R.M., \& Callarisa, L. (2007a). Relationship quality and post purchase perceived value: an integrative framework. European Journal of Marketing, 41 (11/12), 1392-1422.

Moliner, M.A., Sánchez, J., Rodríguez, R.M., \& Callarisa, L. (2007b). Travel agency relationship quality. Annals of Tourism Research, 34 (2), 537-540.

Moliner, M.A., Sánchez, J., Rodríguez, R.M., \& Callarisa, L. (2007c). The relationship 
quality with a travel agency: the influence of the postpurchase perceived value of a tourism package. Tourism and Hospitality Research, 7 (3/4), 194-212.

Moliner, M.A., Sánchez, J., Rodríguez, R.M., \& Callarisa, L. (2007d). Calidad de la relación de las agencias de viajes. Annals of Tourism Research, 9 (1), 195-199.

Moliner, M.A. (2009). Loyalty, perceived value, relationship quality and agency Theory. Journal of Service Management, 20 (1), 76-97.

Monferrer, D., Estrada, M., Fandos, J.C., Moliner, M.A., \& Sánchez, J. (2016). Service quality in bank during and economic crisis. International Journal of Bank Marketing, 34 (2), 235-259.

Moorman, C., Deshpandé, R., \& Zaltman, G. (1993). Factors affecting trust in market research relationships. Journal of Marketing, 57, 81-101.

Moorthi, Y.L.R. \& Mohan, B.C. (2017). Brand value proposition for bank customers in India. International Journal of Bank Marketing, 35 (1), 24-44.

Morgan, R.M., \& Hunt, S.D. (1994). The commitment-trust theory of relationship marketing. Journal of Marketing, 58 (3), 20-38.

Myers, R.H. (1990). Classical and Modern Regression with Applications. Boston, MA: PWS-KENT.

Ndubisi, N.O. (2007). Relationship marketing and customer loyalty. Marketing Intelligence \& Planning, 25 (1), 98-106.

Nunnally, J. (1979). Psychometric Theory. Nueva York, NY: McGraw-Hill.

Oliver, R.L. (1981). Measurement and evaluation of satisfaction processes in retail setting. Journal of Retailing, 57 (3), 25-48.

Oliver, R.L. (1999). Whence consumer loyalty? Journal of Marketing, 63, 33-44.

Olorunniwo, F., Hsu, M.K., \& Udo, G.J. (2006). Service quality, customer satisfaction, and behavioral intentions in the service factory. Journal of Services Marketing, $20(1), 59-72$.

O'Toole, T. \& Donaldson, B. (2002). Relationship performance dimensions of buyersupplier exchanges. European Journal of Purchasing and Supply Management, $8(4), 197-207$. 
Pansari, A. \& Kumar, V. (2017). Customer engagement: the construct, antecedents, and consequences. Journal of the Academy of Marketing Science, 45 (3), 294-311.

Parasuraman, A., Zeithaml, V.A., \& Berry, L.L. (1994). Reassessment of expectations as a comparison standard in measuring service quality: Implications for future research. Journal of Marketing, 58 (1), 111-124.

Pérez, A., \& Rodríguez, I. (2015). Customer responses to the CSR of banking companies. Journal of Product and Brand Management, 24 (5), 481-493.

Podsakoff, P.M., Mackenzie, S.B., Lee, J.Y., \& Podsakoff, N.P. (2003). Common method biases in behavioral research: A critical review of the literature and recommended remedies. Journal of Applied Psychology, 88 (5), 879-903.

Roberts, K.; Varki, S., \& Brodie, R. (2003). Measuring the quality of relationships in consumer services: An empirical study. European Journal of Marketing, 37, 169-196.

Rollins, M., Nickell, D., \& Ennis, J. (2014). The impact of economic downturns on marketing. Journal of Business Research, 67 (1), 2727-2731.

Rotter, J.B. (1967). A new scale for the measurement of interpersonal trust. Journal of Personality, 35 (4), 651-665.

Roy, R. \& Rabbanee, F.K. (2015). Antecedents and consequences of self-congruity. European Journal of Marketing, 49 (3/4), 444-466.

Rozell, E.J., Pettijohn, C.E., \& Parker, R.S. (2004). Customer-oriented selling: Exploring the roles of emotional intelligence and organizational commitment. Psychology and Marketing, 21 (6), 405-424.

Salovey, P., \& Mayer, J.D. (1990). Emotional intelligence. Imagination, cognition and personality, 9 (3), 185-211.

Sánchez, J., Moliner, M.A., Callarisa, L. \& Rodríguez, R.M. (2007). Relationship quality of an establishment and perceived value of a purchase. The Service Industries Journal, 27 (2), 151-174.

Sanchis, J.R. (2013). La banca que necesitamos. Valencia: PUV Universidad de Valencia.

Sanz, A. (2002). Inteligencia Emocional. España: Hobby Club S.A. 
Sayani, H. (2015). Customer satisfaction and loyalty in the United Arab Emirates banking industry. International Journal of Bank Marketing, 33 (3), 351-375.

Schoefer, K., \& Ennew, C. (2005). The impact of perceived justice on consumers' emotional responses to service complaint experiences. Journal of Services Marketing, 19 (5), 261-270.

Segarra, P. (2007). Influencia de la heterogeneidad del mercado en la intención de comportamiento del consumidor: Respuestas a la actividad relacional en la distribución de gran consumo. Tarragona: Universidad Rovira y Virgili.

Segarra, J.R., Moliner, M.A., \& Sánchez, J. (2013). Relationship quality in business to business: A cross-cultural perspective from universities. Marketing Intelligence and Planning, 31(3), 196-215.

Shainesh, G. (2012). Effects of trustwortheiness and trust on loyalty intentions. International of Bank Marketing, 30 (4), 267-279.

Sharifi, S.S., \& Esfidani, M.R. (2014). The impacts of relationship marketing on cognitive dissonance, satisfaction, and loyalty: The mediating role of trust and cognitive dissonance. International Journal of Retail \& Distribution Management, 42 (6), 7-7.

Sierra, B., Alier, E., \& Falces, C. (2000). Los efectos de las variables ambientales sobre la conducta del consumidor. Distribución y Consumo, 54, 5-21.

Smith, A.M. (2006). A cross-cultural perspective on the role of emotion in negative service encounters. The Service Industries Journal, 26 (7), 709-726.

Smith, A.K., \& Bolton, R.N. (2002). The effect of customers' emotional responses to service failures on their recovery effort evaluations and satisfaction judgements. Journal of the Academy of Marketing Science, 30 (1), 5-23.

Sparks, B.A. \& McColl, J.C. (2001). Justice strategy options for increased customer satisfaction in a services recovery setting. Journal of Business Research, 54, 209-218.

Steenkamp, J.E.M. \& Van Trijp, H.C.M. (1991). The use of LISREL in validating marketing constructs. International Journal of Research in Marketing, 8, 283299. 
Szymanski, D.M., \& Henard, D.H. (2001). A meta-analysis of the empirical evidence. Journal of the Academy of Marketing Science, 29 (1), 16-35.

Tortosa, V., Llorens, J., Moliner, M.A., Sánchez, J. (2015). The influence of internal market orientation on external outcomes. Journal of Service Theory and Practice, 25 (4), 486-523.

Trif, S.M. (2013). The influence of overall satisfaction and trust on customer loyalty. Management and Marketing, 8 (1), 109-128.

Tsarenko, Y., \& Strizhakova, Y. (2013). Coping with service failures: The role of emotional intelligence, self-efficacy and intention to complain. European Journal of Marketing, 47 (1/2), 71-92.

Ulaga, W. \& Eggert, A. (2006). Relationship value and relationship quality: Broadening the nomological network of business- to- business relationships. European Journal of Marketing, 40 (3/4), 311-327.

Verleye, K. (2015). The co-creation experience from the customer perspective: its measurement and determinants. Journal of Service Management, 26 (2), 321342.

Vigoda, E., \& Meisler G. (2010). Emotions in management and the management of emotions: The impact of Emotional Intelligence and organizational politics on public sector employees. Public Administration Review, Jan-Feb, 72-86.

White, C.J. (2006). Towards an understanding of the relationship between mood, emotions, service quality and customer loyalty intentions. The Service Industries Journal, 26 (8), 837-847.

Wong, C.S. Wong, P.M., \& Law, K.S. (2007). Evidence on the practical utility of Wong's emotional intelligence scale in Hong Kong and mainland China. Asia Pacific Journal of Management, 24(1), 43-60.

Woodruff, R.B. \& Gardial, S.F. (1996). Know your customer: new approaches to understanding customer value and satisfaction. Cambridge, MA: Blackwell Publications.

Woodside, A.G., Frey, L.L., \& Daly, R.T. (1989). Linking service quality, customer satisfaction, and behavioral intention. Journal of Health Care Marketing, 9 (4), $5-17$. 
Yi, Y. (1990). A critical review of consumer satisfaction. Review of Marketing, 4, 68123.

Zárate, R., \& Matviuk, S. (2010). La inteligencia emocional y el sector financiero colombiano. Revista Escuela de Administración de Negocios, 69, 148-165.

Zeidner, M., Matthews, G., \& Roberts, R.D. (2004). Emotional Intelligence in the workplace: A critical review. Applied Psychology: An International Review, 53 (3), 371-399. 
Figure 1. Shows the research model with all the proposed hypotheses

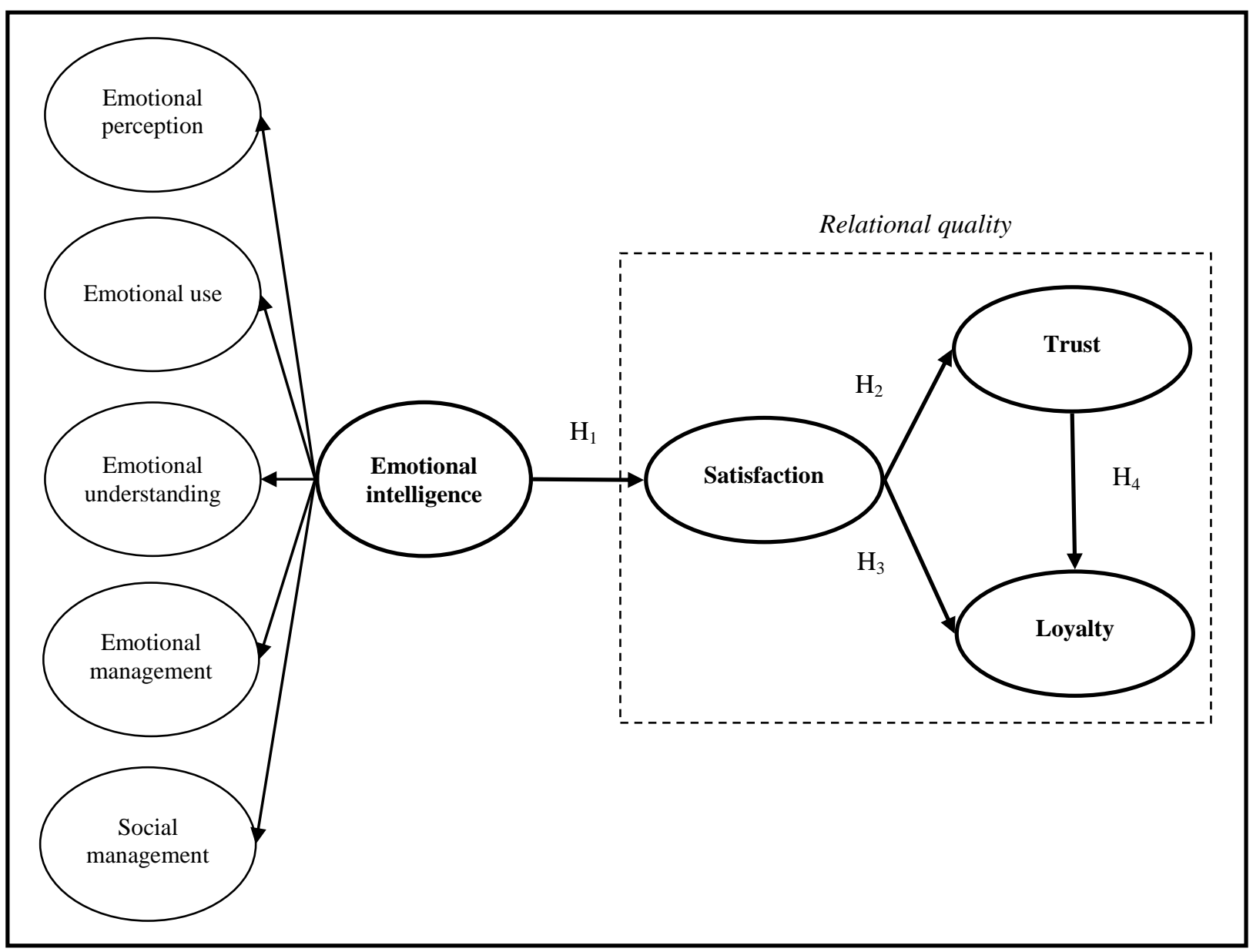

Table 1. General characteristics of the sample

\begin{tabular}{|c|c|c|c|c|c|c|c|}
\hline \multicolumn{2}{|l|}{ Age } & \multicolumn{2}{|l|}{ Occupation } & \multicolumn{2}{|l|}{ Education level } & \multicolumn{2}{|l|}{ Income level } \\
\hline Years & $\%$ & Rank & $\%$ & Level & $\%$ & Level & $\%$ \\
\hline $18-29$ & 15 & \multirow{2}{*}{ Student } & \multirow{2}{*}{10} & No studies & 4 & $0-1000 €$ & 18 \\
\hline $30-39$ & 20 & & & Primary education & 15 & $1001-1500 €$ & 28 \\
\hline $40-49$ & 21 & \multirow{2}{*}{ Employed } & \multirow{2}{*}{50} & Secondary education & 19 & $1501-2000 €$ & 24 \\
\hline $50-59$ & 19 & & & High school diploma & 30 & $2001-2500 €$ & 13 \\
\hline $60-69$ & 14 & Homemaker & 10 & Higher education & 32 & $>2500 €$ & 17 \\
\hline \multirow[t]{2}{*}{$>70$} & 11 & \multirow{2}{*}{ Retired } & \multirow{2}{*}{20} & Gender & & & \\
\hline & & & & Rank & \multicolumn{2}{|c|}{$\%$} & \\
\hline \multirow{2}{*}{\multicolumn{2}{|c|}{ Average age $=47$}} & \multirow{2}{*}{ Unemployed } & \multirow{2}{*}{10} & Men & \multirow{2}{*}{\multicolumn{2}{|c|}{$\begin{array}{l}48 \\
52\end{array}$}} & \\
\hline & & & & Women & & & \\
\hline
\end{tabular}


Table 2. Summary of the results after factor, reliability and validity analysis

\begin{tabular}{|c|c|c|}
\hline Items & $\begin{array}{l}\text { Factor } \\
\text { load }\end{array}$ & t-value \\
\hline \multicolumn{3}{|l|}{ EMOTIONAL INTELLIGENCE $(\mathrm{CR}=0.85 ; \mathrm{AVE}=0.53)$} \\
\hline Emotional perception capability $(\alpha=0.922 ; \mathrm{CR}=0.92 ; \mathrm{AVE}=0.75)$ & 0.622 & $11.906^{*}$ \\
\hline $\begin{array}{l}\text { EI.PER.1 - I can tell when a bank employee is not sincere in what he or she } \\
\text { says. }\end{array}$ & 0.800 & Fixed \\
\hline $\begin{array}{l}\text { EI.PER. } 2 \text { - When I address a bank employee I can predict their reaction from } \\
\text { their facial expression. }\end{array}$ & 0.908 & $27.239 *$ \\
\hline $\begin{array}{l}\text { EI.PER.3 - I can tell when a bank employee is only pretending to be polite to } \\
\text { me. }\end{array}$ & 0.898 & $18.537^{*}$ \\
\hline $\begin{array}{l}\text { EI.PER. } 4 \text { - When I address a bank employee I can predict their reaction from } \\
\text { their body language. }\end{array}$ & 0.851 & $19.819^{*}$ \\
\hline Emotional use capability $(\alpha=0.881 ; \mathrm{CR}=0.89 ; \mathrm{AVE}=0.72)$ & 0.828 & $18.954 *$ \\
\hline $\begin{array}{l}\text { EI.USE.1 - If I have received poor service, I assess my emotional state before } \\
\text { taking any decision. }\end{array}$ & 0.886 & Fixed \\
\hline $\begin{array}{l}\text { EI.USE. } 2 \text { - If I have received poor service, I use different emotions to see it } \\
\text { from different approaches. }\end{array}$ & 0.854 & $33.671 *$ \\
\hline EI.USE. 3 - I trust my emotions to make the right response to a service failure. & 0.805 & $24.496^{*}$ \\
\hline Emotional understanding capability $(\alpha=0.919 ; \mathrm{CR}=0.92 ; \mathrm{AVE}=0.75)$ & 0.735 & $14.957^{*}$ \\
\hline EI.UND. 1 - During a service experience I can identify the emotions I feel. & 0.808 & Fixed \\
\hline EI.UND. 2 - I can explain the emotions I feel. & 0.934 & $32.022 *$ \\
\hline EI.UND. 3 - I can talk about the emotions I feel. & 0.912 & $31.014 *$ \\
\hline EI.UND.4 - If I feel bad, I know what will make me feel better. & 0.796 & $26.506^{*}$ \\
\hline Emotional management capability $(\alpha=0.925 ; \mathrm{CR}=0.93 ; \mathrm{AVE}=0.77)$ & 0.713 & $15.188^{*}$ \\
\hline $\begin{array}{l}\text { EI.M.EMO.1 - I can appear to be calm even when I am annoyed with an } \\
\text { employee. }\end{array}$ & 0.727 & Fixed \\
\hline $\begin{array}{l}\text { EI.M.EMO. } 2 \text { - If I am annoyed with an employee I can quickly get over that } \\
\text { emotion. }\end{array}$ & 0.922 & $27.855^{*}$ \\
\hline $\begin{array}{l}\text { EI.M.EMO. } 3 \text { - When I feel frustrated with an employee, I can get over my } \\
\text { frustration. }\end{array}$ & 0.931 & $26.487^{*}$ \\
\hline $\begin{array}{l}\text { EI.M.EMO.4 - If I feel angry with the service, I can quickly get over that } \\
\text { emotion. }\end{array}$ & 0.920 & $25.502 *$ \\
\hline Social management capability $(\alpha=0.908 ; \mathrm{CR}=0.91 ; \mathrm{AVE}=0.72)$ & 0.726 & $15.948 *$ \\
\hline $\begin{array}{l}\text { EI.M.SOC. } 1 \text { - I feel happy when I see other customers treating employees } \\
\text { well. }\end{array}$ & 0.876 & Fixed \\
\hline $\begin{array}{l}\text { EI.M.SOC. } 2 \text { - I get annoyed when I see other customers trying to take } \\
\text { advantage of employees. }\end{array}$ & 0.812 & $31.840 *$ \\
\hline EI.M.SOC.3 - I feel happy when I see other customers being treated well. & 0.880 & $31.194 *$ \\
\hline $\begin{array}{l}\text { EI.M.SOC.4 - I feel unhappy when I see other customers being treated } \\
\text { unfairly. }\end{array}$ & 0.827 & $33.781 *$ \\
\hline \multicolumn{3}{|l|}{ SATISFACTION $(\alpha=0.960 ; \mathrm{CR}=0.96 ; \mathrm{AVE}=0.86)$} \\
\hline SAT.1 - My expectations have been met. & 0.926 & $40.482 *$ \\
\hline SAT.2 - I am satisfied with the value for money offered. & 0.905 & $38.734 *$ \\
\hline SAT.3 - I am satisfied with the service I have received. & \multicolumn{2}{|c|}{ Deleted } \\
\hline SAT.4 - I am satisfied with the company. & 0.921 & $35.148^{*}$ \\
\hline SAT.5 - In general I am really satisfied. & 0.954 & $39.832 *$ \\
\hline \multicolumn{3}{|l|}{$\operatorname{TRUST}(\alpha=0.931 ; \mathrm{CR}=0.93 ; \mathrm{AVE}=0.74)$} \\
\hline TRU.1 - I trust the professional competence of its members. & 0.924 & $37.015^{*}$ \\
\hline $\begin{array}{l}\text { TRU.2 - This branch has sufficient technical resources (facilities, technology, } \\
\text { etc.). }\end{array}$ & 0.848 & $28.739 *$ \\
\hline TRU.3 - The employees in this branch are sufficiently qualified. & 0.702 & $21.729 *$ \\
\hline
\end{tabular}


TRU.4 - I trust the good intentions of the employees in this branch.

TRU.5 - I consider that in general, employees behave ethically.

Deleted

TRU.6 - This bank is serious and keeps its promises.

0.898

$\operatorname{LOYALTY}(\alpha=0.947 ; \mathrm{CR}=0.95 ; \mathrm{AVE}=0.83)$

LOY.1 - I try to visit my usual branch every time I need financial services.

LOY.2 - I will try to continue with my usual branch in the coming years.

0.927

LOY.3 - I will encourage my relatives and friends to become customers at this branch.

Deleted

LOY.4 - As long as I continue to be treated in the same way I do not expect I will change my bank branch.

LOY.5 - When I need a financial service I will come to this branch.

$0.919 \quad 35.323 *$

Note: Fit of the model: $\chi 2=85.351, \mathrm{df}=68, \mathrm{p}$-value $=0.076 ; \mathrm{NFI}=0.993 ; \mathrm{NNFI}=0.994 ; \mathrm{IFI}=0.997 ; \mathrm{CFI}=$ $0.997 ; \mathrm{GFI}=0.988 ; \mathrm{AGFI}=0.970 ; \mathrm{RMR}=0.020 ; \mathrm{RMSEA}=0.025$.

$* p<0.01$

Table 3. Scale discriminant validity

\begin{tabular}{lllll}
\hline & $\mathbf{1}$ & $\mathbf{2}$ & $\mathbf{3}$ & $\mathbf{4}$ \\
\hline 1. Emotional intelligence & 0.73 & & & \\
2. Satisfaction & $0.40^{*}$ & 0.93 & & \\
3. Trust & $0.48^{*}$ & $0.79^{*}$ & 0.86 & \\
4. Loyalty & $0.42^{*}$ & $0.67^{*}$ & $0.77^{*}$ & 0.91 \\
\hline
\end{tabular}

Below the diagonal: correlation estimated between the factors.

Diagonal: square root of AVE.

$* p<0.01$

Table 4. Summary results of the structural model

\begin{tabular}{clccc}
\hline Hyp. & Path & Parameter & t-value & Result \\
\hline $\mathrm{H}_{1}$ & Emotional intelligence $\rightarrow$ Satisfaction & 0.423 & $9.269^{*}$ & Supported \\
$\mathrm{H}_{2}$ & Satisfaction $\rightarrow$ Trust & 0.796 & $27.379^{*}$ & Supported \\
$\mathrm{H}_{3}$ & Satisfaction $\rightarrow$ Loyalty & 0.181 & $4.389^{*}$ & Supported \\
$\mathrm{H}_{4}$ & Trust $\rightarrow$ Loyalty & 0.627 & $14.322^{*}$ & Supported \\
\hline
\end{tabular}

Note: Fit of the model: $\chi 2=108.029, \mathrm{df}=88, \mathrm{p}$-value=0.073; NFI=0.991; NNFI=0.994; IFI=0.997; CFI= $0.997 ; \mathrm{GFI}=0.985 ; \mathrm{AGFI}=0.970 ; \mathrm{RMR}=0.023 ; \mathrm{RMSEA}=0.025$.

$* p<0.01$. 